\title{
Estonian School System Strategic Leadership «Effects» on School Performance
}

\author{
Hasso Kukemelk
}

Tartu Ülikool - Institute of Education (Estonia)

doi: 10.7358/ecps-2015-011-kuke

hasso.kukemelk@ut.ee

\section{GLI «EFFETTI» DELLA LEADERSHIP STRATEGICA DEL SISTEMA SCOLASTICO ESTONE SULLA PERFORMANCE SCOLASTICA}

\begin{abstract}
All Estonian comprehensive and vocational schools and kindergartens, introduced quality management principles based on the "European Foundation for Quality Management" (EFQM) model of excellence starting from September 2006. This study was designed to identify how school improvements towards learning organisations are managed according to the principal's opinion. The questionnaire was developed on the basis of EFQM excellence model criteria incuding five enablers (leadership, policy and strategy, people management, resources and processes) and four results (people satisfaction, customer satisfaction, impact on society, and business results). A five-point "Likert scale» was used in compiling the questionnaire, which was administered as an electronic survey (e-formular). All principals of Estonian elementary and secondary schools were asked to respond (63\% answered) between November 2009 and February 2010. A total number of 327 school principals responded to the questionnaire. The sample was representative for Estonia and the tool was valid for measurement (Cronbach Alpha $>0.89$ in major blocks of the instrument: strategic management, educational processes in school, assessment of school outcomes). The collected data were correlated to national educational statistics (state examination results, further studies, school drop-out, etc.). Average evaluations of school leadership statements by principals were extremely positive. The study indicates that after a three-year implementation of a new managerial system, principals use new terminology but most schools are continuing to run the previous system. The main points of the study are provided with a statistical overview and some recommendations for school development are offered.
\end{abstract}

ECPS Journal - 11/2015

http://www.ledonline.it/ECPS-Journal/ 
Keywords: Assessment of school outcomes, Educational process management, Quality management, Self-evaluation, Strategic management.

\section{INTRODUCTION}

Development of the educational sphere is one of the most important priorities of developed democratic countries. Well-educated people provide an excellent basis to build up a knowledge rich economy and to fight for a major stake in the world economy. Therefore, most countries (not only developed countries) have paid much attention to improving their educational system and to increasing its efficiency and the quality of its graduates. Implementing quality management principles has been a major goal during the last few decades in many educational systems.

The basic principles of quality management were originally developed by Deming for profit-oriented firms and organizations (the PDCA cycle Plan, Do, Check, Act) already in the 1950's (Deming, 2000). Later on, after some successful experiences (first in Japan and later worldwide) the system principles started to be introduced in the public sector (in the 1970s and 1980s) and it became known as New Public Management (NPM) (see, for example, Hays \& Kearney, 1997). There are some major differences in the public sector compared to the private one - the public system is not oriented to profit or competition; there are no clients interested in goods or services, and there is a public interest in a wide range of accessible services provided by the public sector. NPM introduced competition into the public sector and through that into education. This competition creates pressure on schools and teachers who have to improve their educational outputs and pay more attention to students' school performance in an environment where parents and students can choose which school to attend (Dempster, Freakley, \& Parry, 2001).

School performance is considered to be a very important theme in education by many researchers (Bosker \& Scheerens, 2000; Woods \& Levačić, 2002; Dolton \& Newson, 2003; Kukemelk, Lillemaa, \& Tondi, 2011) and education policymakers. Therefore, several researchers have turned to the concept of schools as learning organisations and different school stakeholders' roles in the creation of a learning environment within the organisation. A considerable amount of data concerning different school stakeholders' activities in the educational environment have been presented (e.g. Kalin \& Zuljan, 2007; Sun, Creemers, \& De Jong, 2007). The formation of a learning community within schools is a challenge for every school head as well as 
the involvement of teachers, students and parents in the process. Today, this creates new requirements for the school head professional profile in order to achieve a high student performance within the school.

\section{STUDY BACKGROUND}

Senge shifts the focus from the student as learner to the school as learner (2001). School cultures and structures are growing virtually on a daily basis «so it may be said, one never steps into the same school twice» (MacBeath \& Townsend, 2011, p. 7). School heads are leaders that should create this type of school environment. MacBeath and Townsend state that to achieve the goal (learning centred leadership) schools should:

- Focus on learning (in a broader sense).

- Pay attention to conditions for learning.

- Support dialogue between different stakeholders.

- Develop shared leadership.

- Run efficient (internal) accountability systems.

School performance assessment and its leadership can be considered as one of the most important features to increase the efficiency and the quality of the education system (Türk et al., 2011). A similar concept was stressed by McKinsey \& Company (Mourshed, Chijioke, \& Barber, 2010) in that successful school systems have more trust in schools and teachers and a remarkable amount of decision making in education is entrusted to schools and teachers in those systems. School principals have to play a key role in the processes described above and in creating school managerial systems to meet most of the characteristics describing schools as a learning organisation. This means that teachers and other stakeholders must be actively involved in school development activities and decision-making processes. Different quality management principles and Models of Excellence (ME) have been developed for schools: the Malcolm Baldrige Performance Excellence Model (developed in 1987), the European Foundation for Quality Management (EFQM) Excellence Model (designed in 1991), and so on. The central issue in quality management in an educational institution is the validity of the processes and the principles used in implementing such a system. Steed, Maslow and Mazaletskaya (2005) have described eight main principles for the ME based on EFQM (see Figure 1):

- Customer focus (excellence in creating sustainable customer value).

- Results orientation (excellence in achieving results to please all the organisation's stakeholders). 
- Leadership and constancy of purpose (excellence in visionary and inspirational leadership, coupled with constancy of purpose).

- People development and involvement (excellence in maximising the contribution of employees through their development and involvement).

- Management by processes and facts (excellence in managing the organisation through a set of interdependent and interrelated systems, processes and facts).

- Partnership development (excellence in developing and maintaining valueadding partnerships).

- Corporate social responsibility (excellence in exceeding the minimum regulatory framework in which the organisation operates, and striving to understand and respond to the expectations of their stakeholders in society).

- Continuous learning, innovation and improvement (excellence in challenging the status quo and effecting change by using learning to create innovation and improvement opportunities).

There are several studies demonstrating different experiences and perceptions of implementing ME in education (Lindborg, 2005; Edmund, 2008; Bore \& Wright, 2009; etc.). Several studies indicate problems with the implementation of ME. A study in Kenya (Ngware, Wamukuru, \& Odebero, 2006) indicates (a result of questioning 300 teachers) that if leaders are not providing the necessary leadership to implement ME, then a change in the school culture cannot be achieved. Avis (2006) adds that educational practice is highly complex and that claims of the success with ME are overstated. In some cases, teachers consider leaders implementing ME as «bad», despite the nature of teamwork and collaboration inside the unit (Safakli \& San, 2007). Hendriks and Scheerens (2013) indicate through meta-analysis that it is very complicated to find a link between school leadership and school performance: there is a list of studies finding no connection at all and another list of studies describing some kind of connection.

These studies demonstrate that the implementation of $\mathrm{ME}$ in schools could be a powerful tool, but its implementation is very complicated and a somewhat lengthy procedure. The school principal is one of the main stakeholders in this procedure. Therefore, it is important to study his/her role in the implementation of ME in education and connections to school performance. 


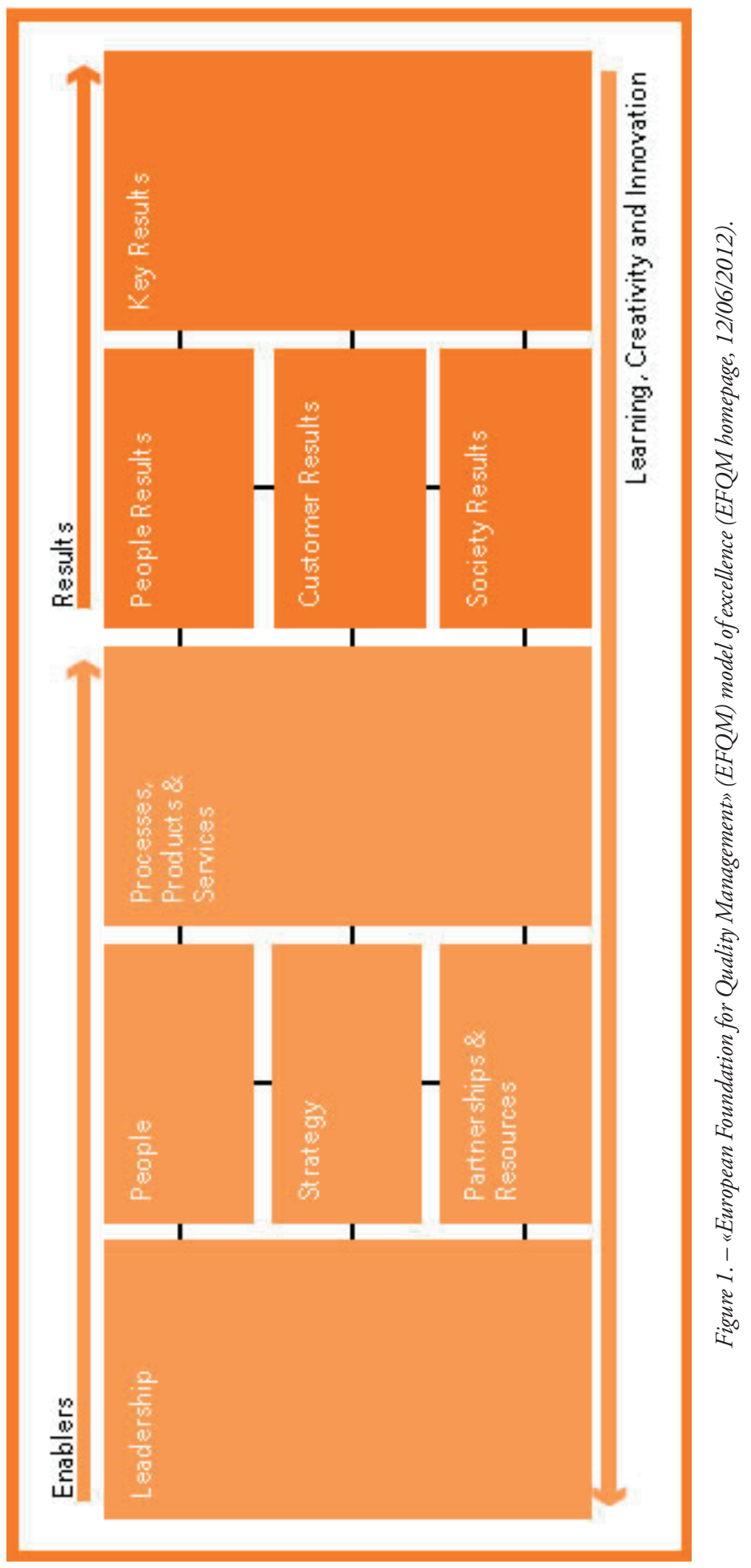




\section{ESTONIAN BACKGROUND}

All comprehensive and vocational schools and kindergartens in Estonia have been obliged to introduce quality management principles as of September 2006 (Regulation nr. 23, Estonian Ministry of Education and Research, August 04 , 2006). The institutions were free to choose their preferred system of self-evaluation, but all supporting and study materials were developed on the basis of the EFQM model. Although minor attempts to introduce various quality management systems on a voluntary basis have been made in Estonia since 2000, the current reform was general and compulsory for every institution (all kindergartens, comprehensive and vocational schools). The first self-evaluation report had to be developed by each institution by spring 2010 at the latest.

The state trained a number of school advisors to support schools and kindergartens to develop their own ME system and design self-evaluation reports. A new regulation was provided by the Estonian Ministry of Education and Research two years later (in 2008) giving schools more freedom, but it did not provide any example indicators on the results of the schools regarding the enablers part of the EFQM model (see Figure 1). This was caused by the schools' input which showed that every school has a specific role in the area and there cannot be any common results indicators compliant with every educational institution mission.

\section{THE STUDY AIM AND SAMPLE}

The aim of the study was to understand how school principals, according to their own opinion, are managing school improvements and developing their schools in the direction of learning organisations. It was part of a major study of Estonian comprehensive and vocational schools. All lower, upper secondary and vocational schools were asked to participate in the study. The study was conducted from November 2009 to January 2010. The target group of the study were school principals. Out of the 487 schools meeting the requirements of the study, only 316 (65\%) responded.

The teaching language in schools could be Estonian or Russian; both types of schools were included in the study. There were 394 schools (80\%) where the teaching language was Estonian, 42 (9\%) where the language was Russian and 51 (11\%) schools using both with an emphasis on the Estonian language according to official statistical data. The proportion of respondents according to the teaching language provided a similar overall picture: $80 \%$ of 
respondents were Estonian and 20\% from Russian or mixed schools. Regardless of the teaching language used, every school principal had to be able to communicate in Estonian at least at an advanced level - C1. This is why the questionnaires were designed only in Estonian for the principals.

All 487 upper and lower secondary school principals were asked to participate in the study. In major studies, similar questionnaires with certain specifications were administered to other stakeholders too - teachers, students (grades 9 and 12), parents, school owners and school-board members. The current study only focused on the principals' responses.

The principals were asked to complete an electronic questionnaire (the questionnaire was sent to them by e-mail and by ordinary mail). Altogether, 327 principals responded to the questionnaire; 114 of whom were males and 208 females ( 5 did not mention their sex). With regard to age, $4 \%$ of the respondents were under 33 years of age, $17 \%$ were $33-42$ years old, 38\% 43-52 years old, $28 \% 53-62$ years old and $4 \%$ over 63 years of age. $9 \%$ of the respondents did not declare their age.

\section{THE INSTRUMENT}

The questionnaire was developed by the research team on the basis of the EFQM excellence model (see Figure 1) criteria, including questions concerning all parts of the ME: five enablers (leadership, policy and strategy, people management, resources, and processes) and four results (people satisfaction, customer satisfaction, impact on society, and business results). The EFQM model was chosen as the basis for the instrument because the Estonian national framework for school self-evaluation was developed on the basis of this model.

The school principal questionnaire included 102 questions; several of these had sub-questions. Two principals first tested the questionnaire and then piloted it to ten Estonian schools in spring 2009 followed by improvements. A six-point Likert scale was used in the questionnaire: 5 meant totally agree 4 - agree, 3 - undecided, 2 - disagree, 1 - totally disagree. A 0 point was added, chosen when the person could not answer the question or had insufficient information to answer. Additionally, a small number of open and background questions were asked. The instrument was developed by the research team at the University of Tartu. The questionnaire was published in an electronic environment using the e-formular software. The reliability of the questionnaire was checked by calculating the Cronbach Alpha for each logical section: it was .89 or more for principals (school strategic leadership .929; educational processes in school .897; and school outcomes .936). 
National educational statistics from 2006 to 2009 were used as the data source. Schools were divided into groups based on the results of factor analyses and according to location (major cities, towns and rural area) and size (small, medium and large). SPSS was used for factor analyses and to calculate correlations and comparisons.

\section{RESULTS AND DISCUSSION}

The principals gave higher marks with respect to other participants to almost every statement of the questionnaire. There were a small number of statements which were assessed higher by teachers. School principals generally assessed statements close to the maximum score and there were thus few statements with a high standard deviation (see Table 1) and even these were mostly about indicators analysing different issues related to school development and the improvement of the teaching environment.

High standard deviation (SD) leads to the conclusion that certain school development issues are not equally important in every school - principals assessed those issues differently and SD is high. The most common value for SD was .66.

Factor analysis was used to indicate key characteristics for school strategic management based on statements assessed by school principals. Three main factors were described:

- Indicators of personal level school efficiency:

- Parent satisfaction with school educational process and schooling outcomes.

- Student satisfaction with school educational process and schooling outcomes.

- Teachers satisfaction with school educational process and schooling outcomes.

- Principals satisfaction with school educational process and schooling outcomes.

- Indicators describing school operative management level:

- School ethics, open communication inside school as institution.

- School orientation to students' high academic outcomes.

- School orientation to students' interests and needs.

- Development of learners supporting school culture.

- Indicators describing school strategic management/leadership level:

- Student performance analysing systems developed and used in school.

- School efficient strategic planning system (existence of school development plan, teachers in-service training plan etc.) - based on Deming Wheel or any other model of excellence (or adopted version).

- School collaboration with local authorities.

- School communication with stakeholders outside school (incl. the media). 
Table 1. - School principals' assessments to EFQM model statements having standard deviations (SD) of 1.0 or greater.

\begin{tabular}{|c|c|c|c|}
\hline $\mathrm{NR}_{\mathrm{R}}$ & STATEMENT & $\begin{array}{l}\text { ARITHMETIC } \\
\text { MEAN }\end{array}$ & SD \\
\hline 1. & $\begin{array}{l}\text { We have updated the school developmental plan during } \\
\text { the last year }\end{array}$ & 4.39 & 1.06 \\
\hline 2. & $\begin{array}{l}\text { Our school has collaborated enough with enterprises } \\
\text { to support students' development }\end{array}$ & 3.29 & 1.02 \\
\hline 3. & $\begin{array}{l}\text { Our school is analyzing students' ratio of teachers } \\
\text { as a teaching quality indicator }\end{array}$ & 3.74 & 1.32 \\
\hline 4. & $\begin{array}{l}\text { Our school is analyzing students' ratio of computers } \\
\text { in our computer labs as a teaching quality indicator }\end{array}$ & 4.08 & 1.16 \\
\hline 5. & $\begin{array}{l}\text { Our school is analyzing teachers' ratio of computers used } \\
\text { for teachers everyday work as a teaching quality indicator }\end{array}$ & 4.15 & 1.07 \\
\hline 6. & $\begin{array}{l}\text { Our school is analyzing school's total cost per student } \\
\text { as a teaching quality indicator }\end{array}$ & 3.93 & 1.1 \\
\hline 7. & $\begin{array}{l}\text { Our school is analyzing teachers' turnover as a teaching } \\
\text { quality indicator }\end{array}$ & 3.97 & 1.17 \\
\hline 8. & $\begin{array}{l}\text { Our school is analyzing violations of teachers' professional } \\
\text { ethics as a teaching quality indicator }\end{array}$ & 3.96 & 1.19 \\
\hline 9. & $\begin{array}{l}\text { Our school is analyzing parents' accessibility to the school } \\
\text { electronic database of students' performance as a teaching } \\
\text { quality indicator }\end{array}$ & 4.15 & 1.26 \\
\hline 10. & $\begin{array}{l}\text { Our school is analyzing students' state examination results } \\
\text { compared to the national average }\end{array}$ & 4.39 & 1.14 \\
\hline 11. & $\begin{array}{l}\text { Our school is analyzing student drop-out from upper } \\
\text { secondary schools }\end{array}$ & 4.05 & 1.41 \\
\hline
\end{tabular}

Pearson's correlation coefficients were calculated between different factors and indicators of national statistics. Several interesting results were discovered; schools which systematically analyse reasons for student drop-out achieve higher results in national examinations $\left(.32^{* *}\right)$ and a better graduation rate at upper secondary school in the nominal time $\left(.31^{* *}\right)$. Issues taking into account students' opinions regarding the planning of the school day were also important: schools taking into account the students' opinions regarding the school timetable attract more new student enrolments. To get more applicants (to have the opportunity to choose students at the upper secondary level) schools should support students councils and take their opinion into consideration. 


\begin{tabular}{|c|c|c|c|}
\hline $\mathrm{NR}_{\mathrm{R}}$ & StATEMENT & $\begin{array}{l}\text { LESS THAN } \\
\text { IOO STUDENTS }\end{array}$ & $\begin{array}{l}\text { MORE THAN } \\
200 \text { STUDENTS }\end{array}$ \\
\hline 1. & $\begin{array}{l}\text { We have evaluated the realisation of the school development } \\
\text { plan during the last } 5 \text { years** }\end{array}$ & 4.31 & 4.64 \\
\hline 2. & $\begin{array}{l}\text { Planning school activities takes into account results of students } \\
\text { and parents' satisfaction studies* }\end{array}$ & 4.28 & 4.47 \\
\hline 3. & $\begin{array}{l}\text { The school leadership team takes into account students' opinions } \\
\text { and proposals in decision making** }\end{array}$ & 4.19 & 4.43 \\
\hline 4. & The school keeps continuous contact with alumni & 3.30 & 3.75 \\
\hline 5. & $\begin{array}{l}\text { The school greatly appreciates teachers achievements } \\
\text { in different fields at local, regional and national level* }\end{array}$ & 4.35 & 4.55 \\
\hline 6. & Teaching in our school is based on students' individual abilities** & 4.31 & 3.84 \\
\hline 7. & $\begin{array}{l}\text { Each student's academic results are analysed systematically } \\
\text { in our school** }\end{array}$ & 4.42 & 4.11 \\
\hline 8. & $\begin{array}{l}\text { Each student's general skills are analysed systematically } \\
\text { in our school* }\end{array}$ & 3.93 & 3.63 \\
\hline 9. & $\begin{array}{l}\text { The list of elective courses in our school meets student } \\
\text { expectations }{ }^{* *}\end{array}$ & 3.28 & 3.76 \\
\hline 10. & Our teachers care for the students** & 4.54 & 4.26 \\
\hline 11. & Teachers treat students fairly in our school* & 4.25 & 4.02 \\
\hline 12. & $\begin{array}{l}\text { A student can always go to the teacher with his/her problem } \\
\text { in our school** }\end{array}$ & 4.50 & 4.18 \\
\hline 13. & $\begin{array}{l}\text { Our school collaborates with the next level educational } \\
\text { institution to support student multisided development }\end{array}$ & 3.85 & 4.16 \\
\hline 14. & $\begin{array}{l}\text { Our school is analysing violations of teachers' professional } \\
\text { ethics** }\end{array}$ & 3.78 & 4.25 \\
\hline 15. & Our school is analysing parents' access to e-school ${ }^{* *}$ & 3.70 & 4.37 \\
\hline 16. & $\begin{array}{l}\text { Our school is analysing results of state examinations } \\
\text { (comparison to the national average) }^{*}\end{array}$ & 4.11 & 4.64 \\
\hline 17. & $\begin{array}{l}\text { Our school is analysing results of state level tests } \\
\text { (comparison to the national average)* }^{*}\end{array}$ & 4.38 & 4.64 \\
\hline 18. & $\begin{array}{l}\text { Our school is analysing reasons for student drop-out from } \\
\text { upper secondary education** }\end{array}$ & 2.83 & 4.57 \\
\hline
\end{tabular}

* Statistically significant difference on the level $p<.05$.

** Statistically significant difference on the level $p<.01$. 
Estonian parents and students were satisfied with the education provided by the school, but they were less satisfied with the methods used in school. This indicates the need to involve parents and students more when planning and designing the school learning environment, and to develop the school culture. At the same time, only half of the students were happy to go to school - another half did not like the school or were neutral. This result again indicates the serious need to improve the everyday social environment in Estonian schools.

Small (rural) schools educated children more to manage everyday problems and major schools (in towns) paid more attention to the students' academic results (see Table 2 ).

Small schools used more student-centred learning approaches and children were happier in those schools. Furthermore, small schools often employed teaching staff who did not meet the national formal teachers' requirements; less active teaching methods were used, more students were repeaters, and their national examination results were 7 points lower (on a 100-point scale).

\section{CONCLUSION}

It is not always very clear what decisions should be taken to develop school systems; e.g. small schools had a more supportive social environment, but less professional teaching staff and poorer student academic results in Estonia. Therefore, it is very important to involve different stakeholders in school development activities, especially students and their parents.

\section{REFERENCES}

Avis, J. (2006). Improvement through research: Policy science or policy scholarship. Research in Post-Compulsory Education, 11(1), 107-114.

Bore, A., \& Wright, N. (2009). The wicked and complex in education: Developing a transdisciplinary perspective for policy formulation, implementation and professional practice. Journal of Education for Teaching, 35(3), 241-256.

Bosker, R. J., \& Scheerens, J. (2000). Publishing school performance data. European Education, 32(3), 12-30.

Deming, W. E. (2000). The new economics for industry, government, education (2nd ed.). Cambridge, MA: MIT Press. 
Dempster, N., Freakley, M., \& Parry, L. (2001). The ethical climate of public schooling under New Public Management. International Journal of Leadership in Education, 4(1), 1-12.

Dolton, P., \& Newson, D. (2003). The relationship between teacher turnover and school performance. London Review of Education, 1(2), 132-140.

Edmund, M. (2008). The architect of quality. Quality Progress, 41(4), 20-25.

EFQM homepage: http://www.efqm.org/en/tabid/392/default.aspx (consulted 25/05/2012).

Hays, S. W., \& Kearney, R. C. (1997). Riding the crest of a wave: The national performance review and public management reform. International Journal of Public Administration, 20(1), 11-40.

Hendriks, M. A., \& Scheerens, J. (2013). School leadership effects revisited: A review of empirical studies guided by indirect-effect models. School Leadership and Management, 33(4), 373-394.

Kalin, J., \& Zuljan, M. V. (2007). Teacher perceptions of the goals of effective school reform and their own role in it. Educational Studies, 33(2), 163-175.

Kukemelk, H., Lillemaa, T., \& Tondi, J. (2011). Teachers professional involvement in creating a general learning environment in Estonian schools. ProcediaSocial and Behavioral Sciences, 11, 47-51.

Lindborg, H. (2005). From quality professional to teacher. Quality Progress, 38(2), 76-77.

MacBeath, J., \& Townsend, T. (2011). Leadership and learning: Paradox, paradigms and principles. In T. Townsend \& J. MacBeath (Eds.), International handbook of leadership for learning (pp. 1-28). Dordrecht - Heidelberg - London - New York: Springer.

Mourshed, M., Chijioke, C., \& Barber, M. (2010). How the world's most improved school systems keep getting better. London: McKinsey \& Co.

Ngware, M. W., Wamukuru, D. K., \& Odebero, S. O. (2006). Total quality management in secondary schools in Kenya: Extent of practice. Quality Assurance in Education: An International Perspective, 14(4), 339-362.

Safakli, O. V., \& San, E. (2007). The appropriateness of principal, teacher and student elements to TQM in learning environment: Case of secondary school in Northern Cyprus. Journal of Transnational Management, 12(3), 39-52.

Senge, P. (2001). Schools that learn. New York: Doubleday.

Steed, C., Maslow, D., \& Mazaletskaya, A. (2005). The EFQM excellence model developing quality management: A British-Russian journey. Higher Education in Europe, 30(3-4), 307-319.

Sun, H., Creemers, B. P. M., \& De Jong, R. (2007). Contextual factors and effective school improvement. School Effectiveness and School Improvement, 18, 93-122. 
Türk, K., Haldma, T., Kukemelk, H., Ploom, K., Irs, R., \& Pukkonen, L. (2011). Üldharidus- ja kutsekoolide tulemuslikkus ja seda mójutavad tegurid. Research report in Estonian. Tartu: Tartu Ülikool.

Woods, P. A., \& Levačić, R. (2002). Raising school performance in the league tables (Part 2): Barriers to responsiveness in three disadvantaged schools. British Educational Research Journal, 28(2), 227-247.

\section{RiassunTO}

A partire dal settembre 2006, tutte le scuole e gli asili estoni hanno introdotto elementi di gestione della qualità basati sul modello di eccellenza "European Foundation for Quality Management" (EFQM). Questo studio è stato progettato al fine di individuare come il miglioramento della scuola sia gestito dal preside nella prospettiva dell'organizzazione dei processi di istruzione. Questo studio è stato progettato per individuare come il preside gestisca l'organizzazione dell'istruzione con la prospettiva di migliorare la scuola. Ė stato sviluppato un questionario sulla base di criteri del modello di eccellenza EFQM che prevedono cinque fattori (leadership, politica e strategia, gestione del personale, risorse e processi) e quattro risultati (soddisfazione delle persone, soddisfazione del cliente, impatto sulla società, e risultati aziendali). Il questionario, che ha utilizzato una "scala Likert" a cinque punti, è stato somministrato attraverso un sondaggio elettronico (e-formulario). Tutti i presidi delle scuole estoni, di base e secondarie, sono stati invitati a rispondere tra novembre 2009 e febbraio 2010 (ha risposto il 63\% per un totale di 327 dirigenti scolastici). Il campione è considerato rappresentativo per l'Estonia e lo strumento è risultato valido per la misurazione (Cronbach Alpha > 0.89; per le sotto-scale più forti dello strumento: gestione strategica, processi educativi nella scuola, valutazione dei risultati scolastici). I dati raccolti sono stati correlati alle statistiche nazionali relative all'istruzione (risultati agli esami di Stato, ulteriori studi, abbandono scolastico, ecc.). In media le valutazioni espresse dai presidi, nelle affermazioni relative alla qualità della leadership scolastica, sono state estremamente positive. Lo studio indica che, dopo l'implementazione di tre anni di un nuovo sistema gestionale, i presidi utilizzano una nuova terminologia, ma la maggior parte delle scuole continuano a eseguire il sistema precedente. I principali punti trattati nello studio sono riferiti al panorama statistico nazionale in rapporto al quale vengono fornite alcune raccomandazioni per lo sviluppo della scuola.

Parole chiave: Auto-valutazione, Gestione dei processi educativi, Gestione della qualità, Gestione strategica, Valutazione dei risultati scolastici. 